\title{
Review of Social Benefits of Green and Sustainable Real Estate Properties
}

\author{
I.J. Onuoha ${ }^{1} \quad$ C.E.Ezedike ${ }^{2}$ \\ 1.Department of Estate Management Faculty of Environmental Sciences Imo State University Owerri Nigeria \\ 2.Department of Geography and Environmental Management Imo State University Owerri Nigeria
}

\begin{abstract}
At present, green real estate development and construction seems to focus largely on mitigating environmental impacts and generating economic and financial returns at both the building and market levels whereas the practice and standards of providing social benefits equally at individual, organizational, institutional and community levels appear to have received less attention. There has been a range of opinions that the cause of this may have been that real estate market participants and industry players are not fully aware or less certain of the social benefits accruable from green building. This paper reviews the social benefits of green and sustainable real estate properties. The study identifies minimization of strain on local infrastructure, reduction in absenteeism, boosts in creativity, higher morale and lower workforce turnover, users' satisfaction and more control over the environment, setting example in the community and environment among others as the social benefits associated with green building. However, the review empowers the authors to hypothesize that the impact of corporate social responsibility is dependent on the real estate market participant's knowledge of sustainability. The study will be useful to researchers, practitioners and policy makers in real estate development and market who are seeking clearer explanations on key factors that could attract investment in green building.

Keywords: Sustainability, green building benefits, corporate social responsibility, social indicators, real estate construction, and market participants.

DOI: $10.7176 / \mathrm{JETP} / 9-6-04$
\end{abstract}

Publication date: August $31^{\text {st }} 2019$

\subsection{Introduction}

Within the last two decades, green and sustainable buildings have come to be known as buildings that are mostly designed and constructed with more priorities on environmental and economic benefits. This opinion is largely based on the huge environmental and economic footprints of green buildings, especially when considering the high reliance on energy and water saving, as well as reduction in the operating cost and carbon emission. While the environmental and economic benefits of green building are gradually becoming less contentious, real estate market participants' and policy makers are increasingly becoming more concerned about key sustainable components and factors that can guarantee a healthier, lively, and socially strong communities (Heerwagen, 2000). In the meantime, there are subjective evidences that the price of a building could be connected to the building's apparent level of social sustainability of meeting corporate and community responsibilities (Orians and Heerwagen, 1992; Heerwagen, 2012; Onuoha et al, 2017a). In addition, Heerwagen (2000); and Onuoha et al (2017a) show that green and sustainable real estate is situated within a marketplace that is influenced by many social factors. They observe that the social and ethical responsibility of investing in green building has gradually shifted to owners, developers, property companies and investors who are considered to be agents of achieving healthy, lively, and socially strong communities.

While this study agrees that this change in perception is gradually moving the green real estate property market towards increased levels of social sustainability, it equally add that stakeholders in the green building industry are not fully aware or less certain of the social benefits of green building otherwise there would have been increase in green building by now with critical emphasizes on ethical business operations and corporate social responsibility. As posited by Onuoha et al (2017b) real estate market participants are completely less mindful of the expected social benefits from green building. Besides, there are uncertainties and fears among clients, institutional investors and property development companies when it comes to social benefits of green building. This is because the social benefits for green building are still based on subjective evidences and have remained less explored (Onuoha 2017c). Perhaps this is why Heerwagen (2000) and Onuoha (2017c) had cautioned green building investors to pause and reflect on green building social motivators and benefits before they begin to invest.

Furthermore, Yam (2012) has warned property companies to think of the social responsibilities of going green before they commit to green building. The author cautioned investors to be more environmentally and socially responsible when it comes to green construction. Yam (2012) warning may have been motivated by the adverse impact the property industry has exerted on the environment which has become top building related issue that worries society mostly (UNEPFI, 2008). For example, studies show that buildings contribute up to 50 percent of energy consumption, 16 percent of water usage; 50 percent of $\mathrm{CO} 2$ emissions, 40 percent of solid 
waste, and 40 percent of raw material used (Boyd, 2006; CBRE, 2007; Newell and Manaf, 2008; Von Paumgartten, 2003; Wilkinson and Reed, 2008; Yam, 2012). All these have significant impact on the environment. Thus, industry players such as property developers, investors, owners and tenants are now more worried about the future of our environment and community.

Scholars say that green building is part of the solution to this problem (Kok et al, 2012; Nurul and Zainul, 2013; Onuoha et al, 2017a). This is because the concept of green building largely underscores investment in environmental and eco-friendly properties for the purpose of achieving not only environmental and economic benefits but also social benefits. As a result, many studies (Heerwagen and Orians, 1993; Heerwagen, 2000; Boyden, 2004; Kok et al, 2012; Mohamad et al., 2015; Onuoha 2017c) have discussed the social relationship and benefits between green building and the people. For example, Kok et al (2012) found evidence linking tenants demand for green real estate to enhanced reputation benefits and corporate social responsibility. Such a move in tenants 'desire for green building could mean that tenants are using the buildings that they occupy to communicate their corporate vision to shareholders and employees (Nurul and Zainul, 2013; Onuoha et al, $2017 \mathrm{~b}$ ). The implication is that social factors could rouse the motivation and decision to undertake socially desirable actions such as going green. Therefore, ethical responsibility of caring for the environment and social pressure to meet the needs of communities and organizations could motivate the decision to go green.

For example, foremost societies all over the globe admitted that persons want to live in beautiful and contented home environment and abundant green spaces, and closeness to transport and offices (Heerwagen, 2000). As reported by Green-Homes (2013a) the cognitive motivating decisions to curb strains on local infrastructures in a community could be regarded as social responsibility. Such motive may be driven by the intention to minimize damage on structures such as landfills, aquatic source, tempest water drains, reclaim and produce green space, transport expansion and repairs for roads (Ian, 2010; Green-Homes, 2013b). Related to this, is user's satisfaction and reduction in absenteeism that improves output of workers and has the ability to attract and retain workers (Isa et al., 2013; Nduka and Ogunsanmi, 2015). Regardless of this, studies in the behavioral sciences according to Orians and Heerwagen, (1992) Heerwagen and Orians, (1993) and Boyden (2004) show that a decent green residential and office building brings about: relationship to nature; community uniformity and sense of belonging; behavioral decision and control; opportunity for habitual exercise and activities, tangible variability and security when required.

While Boyd (2005) and Berit (2010) argue that the motive to meet social responsibility has remained one of the attributes of green and sustainable buildings. The authors hypothesized that sentiments of prosperity, style, wellbeing and solace, security and client happiness, reasonable living environment and social incorporation could be guaranteed in a green environment. Furthermore, recent work of Mohamad et al., (2015) found that one of the factors that drive buyers to purchase green properties is green space. The authors found that green real estate owners consider accessibility to green space before investing in green properties. Thus, green building offers this key resource. Akin to this view, Isa et al. (2015) posit that corporate social responsibility has remained a motivating factor for investors and developers in green building. However, research has shown that corporate social responsibility CSR awareness and reporting in relation to sustainability is still low particularly in developing countries (Thompson and Zakaria, 2004). This has been attributed to less concerted effort or motivation on the part of top management and the government to ensure that property companies are reporting their corporate social responsibility activities when it comes to green building (Nurul and Zainul, 2013). Real estate corporate entities and individuals tend to focus more on in-house human resources issues whereas ecological and community social issues are poorly addressed (Bursa Malaysia, 2007; Thompson and Zakaria, 2004; Nwokoro and Onukwube, 2011). Against this backdrop, and the preceding varying opinions, this study reviews the wide range of social variables and benefits that could affect green building adoption.

\subsection{Social Benefits and Motivators of Green Real Estate Properties 2.1 Minimization of strain on local infrastructure}

There is increasing body of evidence that green building broadens local infrastructure. For example, condensed energy and material needs tied with proper sitting help stretch the capacity of public structures for grid-supplies power, water, wastewater, and transportation (Green Home 2013ab). Furthermore, Heerwagen (2000) and the more recent work of Onuoha (2017c) observe that green building minimizes damage on infrastructure such as landfills, water supply, storm water sewers and related development and costs; transportation development, road and rail network and maintenance for roadways and supports better performance of mass communication and transit system. Besides, availability of modern green infrastructure help users and occupants feel healthier (Mansor and Ismail, 2012; Ely and Sheryn, 2014). Similarly, it makes municipalities and countries to maintain their competitive edge in a highly competitive global environment while evolving knowledge economy and knowledge society (Corey, 2004). This is evident in rapidly growing country like Nigeria which has cities and states that predominantly display high densities (Onuoha, 2017c). Thus, the motivation and interest for access to urban infrastructure, for example, road network street systems, clean water, sewerage, energy and 
telecommunication are supported by green building.

For instance, recent study by Mohamad et al., (2015) established that eco-mobility with adequate transportation and green infrastructural system rank high as a factor that influence a property owner to demand for green properties. Green infrastructure is the resilient landscapes that support ecological, economic and human interest by maintaining the integrity of, and promoting landscape connectivity, whilst enhancing the quality of life, place and the environment across different landscape boundaries (Ian, 2010). The author further contend that green infrastructure is the physical setting within and linking cities, towns, and villages, a network of open spaces, waterways, gardens, woodlands, green corridors, street trees etc. that carries many social, economic and ecological gains to local persons and neighborhood while minimizing strains. The above definitions tend to suggest that green or sustainable building consumption add to the overall value of life of the consumer or buyer or a community in a number of ways. They include; occupants who felt increase in jobs in a workplace due to stresses and traumas could have contentment, health, and productivity in a green setting; tenants and users may likewise appreciate all the more satisfying and productive travels to work and less movement congestion in their communities if municipal or substitute transport frameworks are made available at their work environment of which green building guarantees (Ian, 2010). This supports Boyd (2005) proposed benchmark for green building as shown in Table 1.

Table 1 Proposed Social Benchmark for Green Building

\begin{tabular}{|c|c|}
\hline Health and Safety & $\begin{array}{l}\text { compliance with } \mathrm{H} \& \mathrm{~S} \text { regulations and appropriate signage } \\
\text { adequate public liability and service provider insurance } \\
\text { awareness and training of emergency evacuation and accident first aid procedures } \\
\text { for all floor wardens } \\
\text { a first aid station accessible to all building users }\end{array}$ \\
\hline $\begin{array}{l}\text { Stakeholder } \\
\text { Relations }\end{array}$ & $\begin{array}{l}\text { monitoring of stakeholder concerns, views and provisions } \\
\text { transparency and disclosure of landlord/tenant contracts and marketing agreements } \\
\text { supportive use and occupation guidelines for tenants } \\
\text { appropriate training for security and public relations personnel }\end{array}$ \\
\hline $\begin{array}{l}\text { Community } \\
\text { Engagement }\end{array}$ & $\begin{array}{l}\text { encouragement of employment of local residents within the building } \\
\text { provision of accessible public facilities } \\
\text { promotion of and linkage to local service providers } \\
\text { accessible communication channels with building stakeholders }\end{array}$ \\
\hline Accessibility & $\begin{array}{l}\text { connections to designated green spaces } \\
\text { proximity to urban spaces (town centres, malls, etc) } \\
\text { wheelchair access } \\
\text { proximity to child minding facilities }\end{array}$ \\
\hline $\begin{array}{l}\text { Occupier } \\
\text { Satisfaction } \\
\text { and Productivity }\end{array}$ & $\begin{array}{l}\text { quality of communal service areas } \\
\text { complementary usage of building (compatible tenants) } \\
\text { occupant productivity in terms of satisfaction and physical wellbeing }\end{array}$ \\
\hline Cultural Issues & $\begin{array}{l}\text { recognition of indigenous people through cultural space and communication of site } \\
\text { history } \\
\text { consideration of gender equity and minority group requirements } \\
\text { preservation of heritage values } \\
\text { value of artwork as percentage of the fit out }\end{array}$ \\
\hline Local Impacts & $\begin{array}{l}\text { aesthetic implications (compliance with precinct theme, building scale, etc.) } \\
\text { practical implications (traffic generation, off-street emergency parking and } \\
\text { pedestrian management) } \\
\text { nature of tenant businesses and naming rights } \\
\text { community linkages and sponsorship of local neighborhood activities }\end{array}$ \\
\hline
\end{tabular}

Source: Boyd (2005)

\subsection{Reduction in Absenteeism}

One of the benefits of green building is the control of temperature and ventilation with increase natural lighting that leads to improved employee attendance and health in the building (Milad et al., 2014). Mohd et al. (2013) had argued that an important benefit of investing in green buildings is to achieve improved employee attendance and health and the quality of indoor environment. Similarly, the authors had found indoor environmental quality that reduces absenteeism as one of the favorable green features that influence property owners to go green. While Dahiru et al. (2014a, 2014b) apart from reduction in absenteeism, found evidence linking retention of employees and workers as attributes of green building adoption. For example, the U.S Green Building Council reported that employees who work in green offices had a 15\% drop in employee absenteeism (Onuoha, 2017). However, Warren and Peter, (2008) had in a different view argued that a conventional building designed and 
constructed with good heating, ventilating and air conditioning (HVAC) systems and are of brick veneer structure may not be different from a green building and as such there could be no convincing evidence to believe that green building are more comfortable. But Kats et al. (2003) seems to be at variance with Warren and Peter, (2008) contention when they argued that improved lighting, ventilation and indoor environmental quality as known features of green building that improve workforce productivity. It equally has the capacity to draw and keep workers at work, thus reducing absenteeism from workplace. The authors further contended that it is clear that most conventional buildings are hardly designed and constructed in such a way Warren and Peter (2008) had envisaged. Their argument may have been based on a number of studies which show that green building occupants stay healthier and comfortable and are more productive. For example, a study of 31 green buildings from the city of Seattle as reported by Marc (2013) found that absenteeism was reduced to 40\%. Marc (2013) further reported less and fewer sick days of 30\% among company workers. This further proves that reduction of absenteeism is considered as significant factor in green building consumerism.

\subsection{Boosts creativity, higher morale and lower workforce Turnover}

Whereas thorough and accurate studies on worker attraction and retention in sustainable or green building offices have not been fully carried out, several studies have however shown increased opinions on well-being and productivity associated with sustainable building (Hiscock et al., 2014; Isa et al., 2015). Also, Porter et al (1974) and Isaa et al. (2011) are of the opinion that corporate responsibility conscience and image connected with organizations and corporate bodies that construct or inhabit in sustainable buildings may bring about laborer pride, happiness, contentment, and well-being that could result to creativity, inventiveness, improved morale, and a more positive responsibility to the business. Moreover, it could convey to the building owner the status of attractive employer which thus creates important influence of drawing tenants and retaining high quality and talented employees (Isa et al., 2015). Besides, Sonja et al. (2007) had said that developing and keeping high quality personnel bring additional and long-term financial and performance benefits. This for instance may have made Issa et al. (2011) to persuasively link business value and success of high corporate entities to sustainability practices and adoption.

This means that organizations that make greening a priority may gain by having the capacity to pull in and keep youthful workers who will subsequently be more eager to work harder to ensure that the organization's green potentials are realized and more profits made. Studies have equally revealed that green building could increase and enhance the level of creativity and morale level performance (Heerwagen and Orians, 1993). This could translate to superior product quality, timeliness of output, greater innovation. In a pre-post study of Herman Miller building in Holland, Heerwagen et al. (1992) found a modest increase in output, innovation and high morale that could be credited to green building and green environments. Experts believe that occupants of green buildings are more productive and creative as misery which is often associated to non-green buildings due to poor environment is rid of (Lacey, 2010; Rao et al., 2012; Gray and Birrell, 2014). This suggests that green building boots creativity and high morale performance as occupants or workers would come up with new ideas and solve complex problems.

\subsection{Users satisfaction and more control over the environment}

Studies on motivational demand for green buildings have found a clear link between satisfaction and green buildings (Porter et al., 1974; Myers et al., 2007; Maarleveld, 2008; Judith et al., 2013; Onuoha, 2017). There is also a clear proof of correlation with the design of a building and users satisfaction (Leaman and Bordass, 2006). Evidence from studies suggest that there are potentials for green building to enhance users satisfaction (Ng BanHuat and Zainal, 2013; Isa et al., 2015). Similarly, researches show that occupants and employees satisfaction and health as wells as safety are some of the reasons for green building investment (Dahiru, Bala and Azeez, 2014; Dahiru et al., 2014; Nduka and Ogunsanmi, 2015; Onuoha, 2017). According to Aikaterini (2013) many buildings are designed with a green intent to reflect the habitation necessity and further user satisfaction. To realize this, Sara et al. (2011) argued that a modern design, state of the art services and new technology should be incorporated to ensure that buildings meet recognized and satisfied sustainability criteria. Whereas Abbaszadeh et al. (2006); Edwards (2006); Heerwagen and Zagreus (2005) had argued that the most important factor as a benchmark of a buildings success in meeting the design objectives is the level of users satisfaction and social benefits. However, from the perspective of building, Sara et al. (2011) posited that users' prior studies have distinguished between the emphasis on occupants' wellbeing and health. Though, Roulet et al. (2006) had already confirmed that the two factors (workers wellbeing and health) as observed by Sara et al.,(2011) could constitute user satisfaction and could relate to the same social measures for building performance. To Edwards (2006) and Roulet et al. (2006) occupants either feel good, fit and relaxing when they are in the sustainable building. According to Meir et al. (2009) since designers of sustainable buildings incorporate three main mechanisms namely, economic, environmental and social sustainability, it is important to determine a suitable balance between consumer/ buyer motivation and utility of satisfaction. 


\subsection{Setting example in the community and environment}

While many studies found evidence that green building purchasers and consumers like to live in a neighborhood that is visually stimulating which offers comfortable surroundings with unique landscape (Rao et al., 2012; Mohamad et al., 2015), others have identified the benefits to sustain a social setting as a factor that motivates green building (Isa et al. , 2015; Onuoha, 2017). Nduka and Ogunsanmi (2015) observe that green building provides habitable environment through site sustainability while Heerwagen, (2000) posits that the quest for thermal comfort and high quality acoustic environment supports the social attributes of green properties. Whereas most of the studies rationalized the positions of others, others examined the owner and occupant motivating social benefits of green building against conventional buildings (Kats et al., 2003; Rao et al, 2012). For example, Roa et al. (2012) suggest that green buildings in social context provide built environment that assures thermal comfort and acoustic environment than conventional buildings. Furthermore, Adewunmi et al. (2011) observe that users' social satisfaction in sustainable building facilities like hostel facilities are more certain than in conventional building. Adewunmi et al. (2011) and Roa et al (2012) positions may have been based on Lacey (2010) investigation that conventional properties by their nature produces temperature that have effects on workers' productivity. For example, in a study as reported by Lacey (2010) workers performance decreases when temperature rises above 73 to $75 \mathrm{~F}$ while it increases when temperature drops to $72 \mathrm{~F}$. Investigation shows that this could impact on workers social activities (Nurul and Zainul, 2013).

Thus, experts have argued that to avert this, green buildings such as offices with under-floor air distribution system could provide high level of thermal comfort compared to traditional overhead delivery of air which is common in conventional buildings (Lacey, 2010). While acknowledging this assertion, Roa et al. (2012) reported that poor acoustic environment is often associated to conventional buildings which leave tenants and users distracted and even cause headaches sometimes. Accordingly, acoustics are closely linked with human comfort, health and social living considering its influence on human stress level, motivations and productivity (Sonja et al, 2007; Singh et al., 2010; Roa et al., 2012; Aliagha et al, 2013). Again, exposure to noise in a working environment such as offices has been found to have influence on occupants' health performance and productivity as well as social activities (Roa et al., 2012). These authors argued that whereas there are potentially significant gains that could be linked to a well built conventional buildings, the related health issues associated with conventional buildings range from cardiac problems to sickness related to absenteeism and fatigue which have significant effect on social activity. Therefore, poor acoustic environment in properties could not only cause harm to the tenants' physical health but also on their psychological and social health (Leather et al., 2003).

Experts have contended that an emerging concept to the solution is green building that provides built environment that guarantees and assures thermal comfort and high acoustic social environment (Kats et al., 2003; Alev and Baabak, 2010; Roa et al., 2012). This concept could be articulated under the Indoor Environmental Quality (IEQ) criteria which include: indoor air quality, acoustics, visual comfort (lighting), and thermal comfort. Furthermore, green building while setting example in the community, adds to sustainable development through program and services creation and delivery, thus green communities influence and promotes sustainable community development. The utilization of green framework can help keep and preserve open space, boost transport options, lessen solid waste, curtail strain on local infrastructure, right management of storm water and lessening of water pollution, improve air quality and enhance community well-being by planning for growth (Heerwagen, 2000; Ian, 2010). Green building is critical to community education which helps to ease confusion about affordable green housing and help form partnership with neighbors' (Heerwagen, 2000; Ian, 2010). Moreover, green building tends to integrate a community based range of sustainable site mechanism, minimizing site disturbance, re-using native vegetation, planting native plants, and using non-toxic pest control practices, enlightening residents about avoiding injurious pest control products and using green landscaping techniques.

\subsection{Conclusion}

Many real estate stakeholders still believe that the social benefits of green building are still illusions. In other words, many are still bias on views about the social benefits of green construction and create barriers to its full adoption, often without the knowledge of the implications. On the other hand, a lot think that green building is still a matter of choice and luxury and has not become so much of a standard practice. Thus, it will require adoption of an entirely new mindset, which takes a greater degree of awareness and effects into consideration within every decision in the building process to fully understand the social benefits of sustainable buildings. However, this transformation cannot happen without structural changes in the organizational systems and adjustments to professional unconscious value system. Though, this review has clearly shown that green and sustainable building design can have a significant social impact on human health, well being, and work performance, however findings from the study also show evidence of links to environmental and economic value which could be non-quantitative in nature, particularly when it comes to workers productivity and social lives.

The green building positive links to work performance and productivity have been well and reasonably established in this study, but the translation to economic benefits at the organizational level of corporate 
responsibility is not adequately addressed. However, a more promising, but less well researched in this study, is the link between green building features, individual benefits, and organizational cost benefits and effectiveness. Thus, more research is needed in this area. On the other hand, the high impact environmental benefit variables those that affect multiple social benefits for building occupants - are daylight, sunlight, personal control of ambient conditions, and connection to nature (large trees, flowers, gardens and water) have been explained. Nevertheless, the challenge for sustainable building at present is how to fully and sustainably incorporate these elements, especially nature, in urban and social settings where trees, gardens, and parks are not readily available for social activities. It is also evident from the review that improved indoor air quality reduces illness symptoms and absenteeism that can be costly to organizations and individual social behaviors. Thus, there is need to seek ways to completely incorporate nature and naturalistic design features throughout buildings, especially in urban settings which green buildings offer. This has become imperative because sustainable building provide strong emotional bonds between people and the natural world that evolved over the course of human existence in a biometric world. Therefore, real estate developers, civil engineers, designers/architects, and other built environment professionals can create new design approaches that are more effectively link to sustainable practices at the building, neighborhood and community levels. From the review it is clear that the growing interest in social dimensions of sustainability coincides with other social changes. For example, in the work environment, there is increasing concern about social equity and shared access to resources, daylight, and views to the outdoors. For instance, the big corner office, once monopolized by high level executives, is gradually giving way in many organizations to shared meeting spaces, with executive offices moving to the interior away from the window wall (Heerwagen et al, 2005). Workstations with lower partitions and more flexible furnishings are more common as ways to support social awareness and informal communication as well as improve access to daylight and views (Heerwagen et al, 2005; Heerwagen and Zagreus, 2005).

\section{References}

Abbaszadeh, S., Zagreus, L., Leher, D., and Huizenga, C. (2006) Occupant Satisfaction with Indoor Environmental Quality in Green Buildings. Paper presented at the Eighth International Conferenece for Healthy Buildings, Lisbon Portugal

Adewunmi Y, Omirin M and Famuyiwa F (2011) "Post-occupancy evaluation of postgraduate hostel facilities" Facilities 29 (3/4): 149-168.

Aikaterini. M. (2013) The Relationship Between User Satisfaction and Sustainable Building Performance - The case study of Leiderdorps Town Hall. (Msc), Delft University of Technology

Alev, P.D. and Baabak, A.(2010) An Overview of the Benefits and Risk Factors of Going Green in Existing Buildings. International Journal of Facility Management, 1:1, 1-15.

Aliagha, U. G., Maizon, H., Afeez, S. O., and Ali, K. N. (2013). Review of Green Building Demand Factors for Malaysia. Journal of Energy Technologies and Policy, 3(11).

Berit, S. (2010). Impact of Sustainability on Property Values. (Msc Business Administration), University of Regensburge Germany

Boyd, T. (2005). Can we assess the worth of environmental and social characteristics in investment property? Paper presented at the Preoceedings of the PRRES Conference, Auckland New Zealand, School of Construction Management and Property, January 2006.

Boyd, T. (2006), "Evaluating the impact of sustainability on investment property performance", Pacific Rim Property Research Journal, Vol. 12, No. 3, pp. 254-271.

Boyden, S. (2004). The Biology of Civilization: Understanding Human Culture as a Force in Nature. (eds) New South Wales: University of New South WalesPress.

Bursa Malaysia (2007), “CSR 2007 status report”. Retrieved on May 10, 2016 from http://www.bursamalaysia.com.

CB Richard Ellis (2007) "Green downtown office markets: A future reality", CBRE, New York.

Corey, K. (2004) Moving People, Goods, and Information in Singapore: Intelligent Corridors. In R. E. Hanley (Eds.) Moving People, Goods, and Information in the 21st Century: The Cutting Edge Infrastructure of Networked Cities. New York: Routledge

Dahiru, D., Bala, K and Azeez, A.D.A. (2014) Professionals' Perception on the Prospect of Green Building Practices in Nigeria Retrieved on March 20, 2016 from www.irbnet.de/daten/iconda/cib-de26231.pdf.

Dahiru, D., Bala, K and Azeez, A.D.A. (2014a) Professionals' Perception on the Prospect of Green Building Practices in Nigeria. Retrieved on March 20, 2016 from www.irbnet.de/daten/iconda/cib-de26231.pdf.

Dahiru, D., Dania, A.A., and Adejoh, A. (2014b) An Investigation into the Prospect of Green Building Practice in Nigeria. Journal of Sustainable Development 7 (6).

Edward, B. (2006). Benefits of Green Offices in The UK: Analysis from Examples Built in The 1990s. Sustainable Development, 14(3), 190-204.

Ely. M., and Sheryn, P. (2014). Green Infrastructure- Life Support for Human Habitats, the compelling Evidence 
for Incorporating Nature into Urban Environments. Report of Green Infrastructure Project Botanic Gardens of South Australia. Retrieved March 13, 2016 from www.botanicgardens,sa.gov.au/greeninfrastrcuture

Gray, T., and Birrell, C. (2014) Are Biophilic Designed Site Office Buildings Linked to Health Benefits and High Performing Occupants? International Journal of Environmental Research and Public Health 11 (12) 12204-12222

Green, Homes (2013a). The Benefits of Green Building to Homeowners. Retrieved December 26, 2013 from http://www.hgtvremodels.com/interiors/a-greenbuilding- overview/i..

Green-Homes. (2013b). A Green Building Overview: Minimizing The Residential Sector's Toll on The Environment with 10 Practices. Retrieved on March 26, 2016 from http://www.hgtvremodels.com/interiors/a-green-buildingoverview/i...

Heerwagen, J. (2000). Green Buildings and Worker Well Being. EnvironmentalDesign and Construction, 2429

Heerwagen, J. H. (2012) Investing in People: The Social Benefits of Sustainable Design Seattle, Washington: University of Washington

Heerwagen, J. H., and Orians, H. G. (1993). Human, habitats and aesthetics. In S R Kellert and E O Wilson(Eds) The Biophilia Hypothesis Washington DC: Island Press, Shearwater Books.

Heerwagen, J., and Zagreus, L. (2005). The Human Factors of Sustainability: Post Occupancy Evaluation of The Phillip Merrill Environmental Center. USA: US Department of Energy

Heerwagen, J., Loveland, J., and Diamond, R.. (2005). Post Occupancy Evaluation of Energy Edge Buildings. Seattle, Washington: University of Washington

Hiscock R., Madu, P., Braubach, M., Martuzzi, M., Perez, L., and Sabel, C. (2014) Wellbeing Impacts of City Policies for Reducing Greenhouse Gas Emissions. International Journal of Environ Res and Public Health 11 (12) 12312-12345.

Ian, M. C. (2010). Green Infrastructure: Concept, Perceptions and its Use in Spatial Planning. Doctor of Philosophy, Newcastle University

Isa, M., Rahman, A. M. G. M. M., Sipan, I., and Hwa, K. T. (2013) Factors Affecting Green Office Building Investment in Malaysia. Paper presented at the Asia Pacific International Conference on EnvironmentBahaviour Studies, University of Westminster London, UK. 4-6 September

Issa, M. H., Rankin, J. H., Attalla, M., and Christian, A. J. (2011) Absenteeism, Performance and Occupant Satisfaction with the Indoor Environment of Green Toronto Schools. 20(5), 511 - 523. Retrieved on Mrach 102016 from http://ibe.sagepub.com/content/20/5/511.full.pdf

Judith, I., Thomas, B., Ashild, L. H., Karine, D., Solvar, W., and Sidsel, J. (2013) The Interaction between Building and Users in passive and Zero-energy Housing and Offices: The Role of Interfaces Knowledge and User Commitment. Smart Sustainable Built Environment 2 (1) 43-59.

Kats, G. Leon, A. Adam, B. Evan, M. and Jeff, D. (2003). The cost and Financial Benefits of Green Buildings. Report of California Sustainable Building Task Force. Retrieved March 152016 from www.usgbc.org/Docs/News/News 477.pdf.

Kats, G. Leon, A. Adam, B. Evan, M. and Jeff, D. (2003). The cost and Financial Benefits of Green Buildings. Report of California Sustainable Building Task Force. Retrieved March 152016 from www.usgbc.org/Docs/News/News 477.pdf.

Kok, N; Miller, N.G, and Morris P(2012) The Economics of Green Retrofits. Journal of Sustainable Research, 2012, 4:1, 4-22.

Lacey, M (2010) IEQ Factors Day lighting, Thermal Comfort and Acoustics for Healthy Space. Retrieved on March 152016 from: www.facilitiesnet.com

Leaman, A., and Bordass, A. (2006) Productivity in Buildings: the "Killer" variables. In D. ClementsCroome(ed). Creating the Productive Workplace (2nd Eds.). London and New York: Taylor and Francis.

Leather, P., Beale, D., and Sullivan, L. (2003) Noise, psychosocial stress and their interaction in the workplace. Journal of Environmental Psychology, 23(2), 213-222.

Maarleveld, M. (2008). Evidence-Based Workplace Design and The Role of End-User Participation. Retrieved on March 10, 2016 from www.cfpb.nl/fileadmin/cfpb/images/publicaties/artikelen/2008/eng

Mansor, M., and Ismial, S. (2012) .Green Infrastructure as Green Health Promotion Agenda for Urban Community. Retrieved on April 14, 2016 from www,irep.uum.edu.my/25087/1/greeninfrastruture-asgreen.pdf

Marc, L. (2013). 8 Benefits of Green Buildings. Retrieved on December 21, 2013 from http://greenliving.about.com/od/architecturedesign/tp/green_building_advantages.htm

Meir, A. I., Garb, Y., Jiao, D., and Cicelsky, A. (2009). Post-occupancy Evaluation: An Inevitable Step Towards Sustaianbility. Advances in Building Energy Research, 3(1), 189 - 220.

Milad, S., Esmaeillifar, R., and Shafiei, M.W.M. (2014) Green Building: Strategic Approach to Sustainable Economy. International Journal of Business and Management 2 (7).

Milad, S., Nariman, G., Reza, E., Parnaz, O., and Mohd, W. M. S. (2013) The Investigation of Barriers in 
Developing Green Building in Malaysia. Modern Applied Science, 7 (2)

Mohamad T., Ibrahim, N.A., Asniza-Hamimi, A.T., Ismail, N.A., and Azurawati, Z. (2015). Factors Influencing Buyers to Purchase Green Residential Properties. Ist International Joint Conference of Indonesia-MalaysiaBangladesh-Ireland (IJCIMBI)

Myers, G., Reed, R., and Robinson, J. (2007) The Relationship between Sustainability and The Value of Office Buildings. Paper presented at the 13th Annual Pacific Rim Real Estate Conference Curtin University of Technology, Perth WA. 21 -24 January.

Nduka, D.O., and Ogunsamni. (2015). Stakeholders Perception of Factors Determining the Adoptability of Green Building Practices in Construction Projects in Nigeria. Journal of Environment and Earth Science 5 (2).

Newell, G and Manaf, Z. (2008), “The significance of sustainability practices by the Malaysian property sector", Local Economy, Vol. 23, No. 3, pp. 152-167.

Ng Ban-Huat, and Zainal, A. A. (2013) The Development of a Newly Designed Building Performance Survey Framework for Energy-efficient Building: A Review, International Journal of Application or Innovation in Engineering and Management, 2 (2).

Nurul, A. D., and Zainul, N. A. (2013). Motivation and Expectation of Developers on Green Construction: A Conceptual View. World Academy of Science, Engineering and Technology, 76, 4-27.

Nwokoro, I. and Onukwube, H. (2011). Sustainable or Green Construction in Lagos, Nigeria: Principles, Attributes and Framework. Journal of Sustainable Development, 4:4, 166- 74.

Onuoha I.J; Aliagha G.U; Rahman, M.S.A.; Kalu I.U; Onyike J.A; Okeahialam, S.A (2017b) Green and Sustainable Commercial Property Demand in Malaysia and Nigeria, 2017. Journal of Energy Technologies and Policy, Vol 7, No 9.

Onuoha, I.J (2017c) Model of Demand and Supply Factors Affecting Green Commercial Properties. Ph.D.Dissertation. Universiti Teknologi Malaysia, 2017.

Onuoha, I.J; Norhaya K; Aliagha, G. U; Kalu I.U; Onyike J.A; Okeahialam S.A; Ndu Okoronkwo S.N; SamOtuonye C; Alaka I.N (2017b) Green Tax incentives and other Demand Factors Motivating Green Commercial Property Investment, Journal of Sustainable Real Estate, Vol 9 no, 1. O

Orians, G. H., and Heerwagen, J. H. (1992). Evolved Responses to Landscapes. In TheAdapted Mind: Evolutionary Psychology and the Generation of Culture (Eds) Oxford and New York: Oxford University Press

Porter, L. W., Steer, R. M., Mowday, R. T., and Bouhari, P. V. (1974). Organisational Commitment, Job Satisfaction and Turnover among Psychiatric Techanicians. Applied Psychology, 59(5), 603 - 609.

Roa, S.P; Asrul-Mahjuddin, R.A; Hong-Wan, T; Nurul-Amira, A.J; Nazli-Bin, C.D and Nil Inangda, M.K.D. (2012) Thermal and Acoustic Environmental Requirement for Green Buildings in Malaysia, Journal of Design and Environment (11).

Roulet, A. C., Johner, N., Foradini, F., Bluyssen, P., Cox, C., De-Oliveira, F. E., Aizlewood, C. (2006) Perceived Health and Comfort in Relation to Energy use and Building Characteristics. Building Research and Information, 34(5), 467 - 474.

Sara, W. J., Richard, R. G., and Junaidah, J. (2011). User Satisfaction in Sustainable Office Buildings: A Preliminary Study. Paper presented at the 17th PRRES Pacific Rim Real Estate Society Conference, Gold Coast, Australia

Singh, A., Syal, M., Grady, S. C., and Korkmaz, S. (2010). Effects of Green Buildings on Employee Health and Productivity. American Journal of Public Health, 100(9), 1665-1668.

Sonja, P., Nils, L., and Lucuit, M. (2007). Marketing Green Buildings to Tenants of Leased Properties, Retrieved on January 152015 from http://www. Ibmjournal.com/article/92

Thompson, P., and Zakaria, Z. (2004). Corporate Social Responsibility Reporting in Malaysia: Progress and Prospects. JCC (13).

UNEP Finance Initiative (2008), "Responsible property investing: What the leaders are doing", http://www.unepfi.org/publications/property/index.html (accessed 25 Novemeber 2018).

Von Paumgartten, P. (2003), "The business case for high-performance green buildings: sustainability and its financial impact", Journal of Facilities Management, Vol. 2, pp. 26-32.

Warren, L.P and Peter, A.T. (2008). A comparison of Occupant Comfort and Satisfaction between a Green Building and a Conventional Building. Journal of Building and Environment (43) 1858-1870.

Wilkinson, S. and Reed, R. (2008), Property Development, Routledge, London

Yam, S. (2012) Corporate Social Responsibility and the Malaysian Property Industry, Proceedings of 18th Annual PRRES Conference, Adelaide, Australia, 15-18 January 2012 